in addition to linguistic research in Northern Rhodesia and East Africa, he is visiting various centres on behalf of the British Council. His previous work on African Languages includes the translation of the New Testament into Lingala and a Grammar of Lingala (in French).

\title{
An Anthropological Expedition
}

An anthropological expedition to Nigeria under the joint auspices of the North-western and the Ohio State Universities, U.S.A., is to be undertaken. Dr. J. Harris, who spent 1939 in the Ibo country, and Dr. Bascom, who was in the Yoruba area in 1938, form the personnel, and their terms of reference, so to speak, are 'to study the acculturation of Europeans and Natives in Nigeria'. This will mean they will work in the larger centres of population mainly. With their background of experience, one of the east and the other of the west of Nigeria, they should form an excellent team for the purpose. We wish them every success. 